\title{
Relation of calcium phosphorus product with cardiovascular risk and hscrp in hemodialysis patients
}

\author{
Aslan Celebi, \\ SBU GOP Taksim Training and Research Hospital, department of \\ internal medicine, \\ Bahar Yalcin, \\ Izmit State Hospital, internal medicine, \\ Banu Boyuk, \\ SBU GOP Taksim Training and Research Hospital, department of \\ internal medicine, \\ Murat Altay, \\ SBU GOP Taksim Training and Research Hospital, department of \\ internal medicine, \\ Ismail Ekizoglu, \\ SBU Kanuni Sultan Suleyman Training and Research Hospital, \\ department of internal medicine

\section{Corresponding author} \\ Correspondence to Aslan Celebi, M.D. Department of Internal Medicine, Gaziosmanpasa \\ Taksim Education and Research Hospital, Istanbul 34433, Turkey. \\ Tel +90-212-252-43-00, Fax: +90-212-249-78-04, Mobile phone: 05336495050 \\ The authors declare that there is no conflict of interest regarding the publication of this paper. \\ No grants and other funding.

\section{http://dx.doi.org/10.26739/2573-5616-2017-7-7-4} \\ Abstract: Objective: In extensive studies done on chronic kidney disease (CKD) \\ patients, dysregulated bone mineral metabolism is closely associated with the risk of \\ cardiovascular disease and increased risk of morbidity and mortality is revealed. In this \\ study we examine the relationship between calcium phosphorus product which is known \\ to be an independent risk factor in chronic hemodialysis patients and HsCRP values.
}


Materials-methods: Patients were grouped into two according to presence of ischemic heart disease. In addition, in subgroup analysis of our study, all groups were divided into two according to CaxP levels being under $55(<55)$ (Group A) and over $55(\geq 55)$ (Group B) and again compared in terms of independent ischemic heart disease.

Results: A positive correlation was found between CaxP and HsCRP in hemodialysis patients $(\mathrm{p}<0.001)$. The correlation between CaxP and HsCRP was statistically more significant in ischemic heart disease (IHD) patients compared to non diseased patients $(\mathrm{p}<0.001 ; \mathrm{p}<0.02)$. In the analysis of the subgroup study, it is found that hsCRP values were statistically higher in group A compared to group B $(\mathrm{p}<0.001)$.

Conclusion: In our study, we found asignificant relationship between $\mathrm{CaxP}$ and HsCRP in chronic hemodialysis patients. Also we think that in chronic hemodialysis patients with target $\mathrm{CaxP}$ values $(\mathrm{CaxP}<55 \mathrm{mg} / \mathrm{dl})$, IHD prevalence is low and keeping $\mathrm{CaxP}<55$ with treatment would effect cardiovascular mortality.

Keywords: Calcium phosphorus, HsCRP, cardiovascular risk

\section{INTRODUCTION}

The most important cause of mortality in patients with end-stage renal disease (ESRD) is atherosclerotic vascular complications [1,2]. Bone mineral metabolism is dysregulated in chronic kidney disease (CKD) patients starting from the early stages [3]. In extensive studies done on this population it is determined that dysregulated bone mineral metabolism is closely associated with increased risk of hip fracture, cardiovascular disease and increased morbidity and mortality risk [4-7]. In end-stage renal disease (ESRD) patients, bone mineral densitometry was determined significantly lower than normal population and it is detected that in these patients as the duration of dialysis increases reduction of bone mineral density in densitometer becomes more evident [8].

In recent clinical and experimental studies it is shown that quite similar mechanisms take role with calcification of vascular wall and bone mineral metabolism. In addition to this, an independent relationship between vascular calcification and bone metabolism was found [9-10]. There are publications stating the potential risk factors such as recently described homocystein, C-reactive protein (CRP), interleukin (IL)-6, fibrinogen, soluble intracellular adhesion molecule-1, asymmetric dimethyl arginine, advanced glycation products contributing to accelerated atherosclerosis seen in ESRD patients [11, 12, 13]. In this study, we searched the relation between calcium phosphorus product which is known to be an independent risk factor in chronic hemodialysis patients and HsCRP which is used as a risk marker for cardiovascular diseases. 


\section{MATERIAL AND METHODS}

Our study was cross-sectional retrospective in nature, done by retrospective analysis of files of 91 hemodialysis patients in a private dialysis Center in Istanbul in May 2013 and May 2014. 91 patients who received at least 6 months of regular dialysis, not having any infective and/or inflammatory disease were included in the study. Patients with wbc > 10,000, plt $>400,000$, HIV and HbsAg positivity, malignancy, cachexia, who had gastrointestinal bleeding, and hospitalized for any reason were excluded from the study. Besides the demographic features such as age, gender, primary disease, ischemic heart disease, peri pheral vascular disease; levels of kt/v, calcium, phosphorus, calcium x phosphorus, hsCRP, PTH, WBC, PLT, albumin were obtained retrospectively from the file data of all cases. Patients were grouped into two as having ischemic heart disease or not (patients who had wall movement dysfunction in ecocardiography, positive myocardial perfusion scintigraphy, pathologic Q detected on ECG, stent, CABG surgery were included in the ischemic heart disease group.)

In addition, in subgroup analysis of our study, all groups were divided into two according to CaxP levels $<55$ and $\geq 55$.

\section{STATISTICAL ANALYSIS}

While in the analysis of data with normal distribution student t-test, pearson correlation analysis, linear regression analysis were used, of data with non-normal distribution Mann Whitney $\mathrm{U}$ test, spearman correlation test were used. In single analysis the variables with $\mathrm{p}$ value $<0.25$ were processed with multi ple regression analysis.In categorical variables $X^{2}$ test was used. The data were assessed in SPSS statistical program. Significance level was considered to be $\mathrm{p}<0.05$.

\section{RESULTS}

The average age of the patients was 63.96ë13.34. When we looked at the gender distribution it was $52.7 \%$ women, $47.3 \%$ male. The patients were hemodialysis patients of end stage renal disease with backgrounds of 4 (4.4\%) amyloidosis, $39(42.9 \%)$ diabetes, 22 (24.2\%) hypertension, 15 (16.5\%), idiopathic, 1 (1.1\%) neurogenic bladder, 2 (2.2\%) pyelonephritis, $6(6.6 \%)$ polycystic kidney, 1 (1.1\%), toxic nephropathy, $1(1.1 \%)$ vesicoureteral reflux. Of the patients 29 (31.9\%) had ischemic heart disease, $8 \%$ (8.8) percent had peripheral vascular disease.60 patients had neither ischemic heart disease or peri pheral vascular disease; 29 patients just had 
ischemic heart disease, 39 patients with diabetes had been identified. In all patients with ischemic heart disease diabetes accompanied except for 3 cases, diabetics with undetermined IHD were excluded due to the probability of undiagnosed ischemic heart disease presence (Table 1).

A positive correlation between HsCRP and CaxP was observed (Figure $1, \mathrm{p}<0.001)$. The correlation between CaxP and HsCRP was higher in patients with IHD compared to patients without IHD (Figure 2, p < $0.001 ; \mathrm{p}<0.02)$. HsCRP values in Group A and Group B patients were compared (Figure 3). Along with positive correlation of CaxP product between both groups, it is determined that hsCRP values of patients with CaxP $\geq 55$ (Group A) had statistically more significance than values of Group B $(\mathrm{p}<0.001)$.

In IHD group $\mathrm{kt} / \mathrm{v}$ ratio, calcium value, phosphorus value, CaxP value, HsCRP value were found to be higher $(\mathrm{p}<0.05)$. PTH, wbc, plt and albumin values were similar in both groups $(\mathrm{p}>0.05)$ (Table 2).

With comparison of A and B groups according to the biochemical values, these results were obtained: kt/v value, wbc, PLT and albumin values were similar in both groups, there was no significant difference ( $p>$ 0.05). Calcium, phosphorus, CaxP, HsCRP and PTH values were found statistically higher in group A $(p<0.05)$. Prevalence ratio of IHD and PVD was higher in group A than group B $(\mathrm{p}<0.001)$ (Table 3).

\section{DISCUSSION}

Calcium-phosphorus metabolism alterations starting in the early stages of renal insufficiency negatively affects the cardiovascular system [14,15]. Atherosclerosis and coronary artery disease associated with chronic inflammation are the most important risk factors responsible for mortality and morbidity of end-stage kidney disease. High levels of calcium $x$ phosphorus (CaxP $\geq 55 \mathrm{mg} / \mathrm{dl}$ ) were thought to increase vascular calcification inflammation is thought to play an important role in atherosclerosis. CRP as an inflammation marker is intensely related with increased cardiovascular morbidity and mortality $(16,17)$. In this study we aimed to present the relation of calcium phosphorus product in and HsCRP with each other and with cardiovascular risk in hemodialysis patients. In our study positive relationship between hsCRP and CaxP was observed in chronic hemodialysis patients relationship between hsCRP and CaxP was higher in hemodialysis patients with ischemic heart disease compared to patients without ischemic heart disease. Given the KDOQI clinical 
practice guideline the aim was to keep CaXP $<55 \mathrm{mg} / \mathrm{dl}$ [18]. We found hsCRP lower in patients with CaxP $<55$ compared to patients with CaxP $\geq 55 \mathrm{mg} / \mathrm{dl}$. In the study Ezio Movilli et al did [19], a positive correlation between hsCRP CaxP has been identified were detected higher. HsCRP levels were significantly lower in patients with $\mathrm{CaxP}<55$. In study of Chien-Te, Lee et al [20] direct proportion has been identified between hsCRP levels and serum Ca, P, CaxP levels in accordance with our work; hsCRP value is lower also in patients who reached to the treatment goal (CaxP $<55 \mathrm{mg} / \mathrm{dl})$ compared to patients who did not reached to the treatment goal. In the study of $\mathrm{H}$. Nasri et al [21] positive correlation has been revealed between serum hsCRP logarithm and CaxP in accordance with our study. In another study of Navarro-Gonzalez JF and his friends similar results have been obtained as with ours. In this study, positive relationship between hsCRP and $\mathrm{P}, \mathrm{CaxP}$ has been found [22]. It is known that the calcification is more important than plasma cholesterol levels in development of atherosclerosis in hemodialysis patients. When we looked at the study of $4 \mathrm{D}$ about dialysis patients it was observed that as plasma LDL cholesterol levels were decreased under $75 \mathrm{mg} / \mathrm{dl}$ with 10 $\mathrm{mg} /$ day atorvastatin, morbidity and mortality rates related with ischemic heart disease did not decreased [23]. SHARP study which also includes peritoneal dialysis patients shows reduction of the plasma cholesterol levels does not decrease cardiovascular events in ESRD patients [24]. Similar results are seen in the AURORA study [25]. Calcium, phosphorus, and calcium phosphorus product are high in hemodialysis patients with chronic renal failure;

increase in intima calcification is seen when the pathophysiology of atherosclerosis depend on this is considered [26]. Depending on increased vascular rigidity due to calcification cardiac output in perfusion and blood pressure plays a critical role [27] as a result of narrowing of the vascular lumen. This is why low blood pressure is capable of causing ischemia and threaten patients (for example depending on the fluid removal after dialysis). Frequently seen sudden cardiac deaths (28) in dialysis patients can be explained with this. By contrast, acute myocardial infarction occurring with rupture of lipid and cholesterol-rich plaques in dialysis patients is relatively rare. In $4 \mathrm{D}$ study with up to four-year follow-up period of [23], while myocardial infarction constitutes only 22 percent of cardiac death, sudden cardiac death constitutes 55 percent of deaths. In a recent study of incident dialysis patients within 5 years, as cardiovascular event 
while only 6-8,1 percent had non-fatal myocardial infarction, arrhythmia, heart failure, pericarditis, myocarditis, pulmonary edema or heart death related to the arrest was seen 5 to 7 times more frequently [29]. As a result, plasma cholesterol levels play a minor role in changed atherosclerosis in dialysis patients and this situation explains the before mentioned statin treatment not being effective in dialysis patients. This transformation occurs on which phase of chronic kidney disease and depending on which factors is not yet known. Results of many large-scale randomized, prospective studies suggests that basal hsCRP values may have an important place in determining cardiovascular risk [30-41]. These studies include numerous young/elderly, female/male patients from diverse races. Besides cardiovascular death and myocardial infarction determination, hsCRP is also useful in prognosis of stroke, sudden death and peripheral vascular disease development ; hence, CRP is an important determinant of global vascular risk $(35.36,39)$. When it is considered that the high hsCRP determines future cardiovascular event risk and reducing its levels may be protective, strategies that may affect hsCRP levels gain importance.

Our study was designed as a retrospective and cross-sectional study, though reaching to bigger numbers of IHD patients was aimed during the planning phase of our study, a small number of IHD patients was collected, and this prevents the universalization of results despite the existence of a positive correlation in accordance with the literature in our statistical analysis.

In our study, we found a significant relation between CaxP and HsCRP in hemodialysis patients. It is known that the increase of CaxP product plays a role in vascular calcification and this constitutes a risk for cardiovascular diseases [26]; HsCRP is used as a marker for cardiovascular risk and in the study we have done we found a significant relation between these two parameters. While cardiovascular diseases being the most important mortality reason in chronic hemodialysis patients, as seen in our study, in chronic hemodialysis patients with target CaxP values $(\mathrm{CaxP}<55 \mathrm{mg} / \mathrm{dl})$, IHD rates are lower, by contrast, patients with CaxP $\geq 55$ IHD rates are higher and yet in this group hsCRP levels which is a positive marker were detected higher. Therefore with keeping $\mathrm{CaxP}<55$, we think that IHD and HsCRP would decrease and have an impact on mortality. 


\section{References:}

1. Baigent C, Burbury K, Wheeler D. Premature cardiovasculardisease in chronic renal failure. Lancet 2000; 356:147-15

2. Foley RN, Parfrey PS, Sarnak MJ. Clinical epidemiology ofcardiovascular disease in chronic renal failure. Am J KidneyDis 1998; 32 (Suppl. 5): S112-S119

3. Ambrus C, Marton A, Nemeth ZK, Mucsi I: Bone mineral density in patients on maintenance dialysis. Int Urol Nephrol 2010; 42 (3): 723-739

4. Jadoul M, Albert JM, Akiba T, Akizawa T, Arab L, Bragg-GreshamJL, Mason N, Prutz KG, Young EW, Pisoni RL: Incidence and risk factors for hip or other bone fractures among hemodialysis patients in the Dialysis Outcomes and Practice Patterns Study. Kidney Int2006; 70 (7): 1358-1366

5. Mittalhenkle A, Gillen DL, Stehman-Breen CO: Increased risk ofmortality associated with hip fracture in the dialysis population. AmJ Kidney Dis 2004; 44 (4): 672-679

6. Ketteler M, Gross ML, Ritz E: Calcification and cardiovascularproblems in renal failure. Kidney Int Suppl 2005 (94): 120-127

7. Matsubara K, Suliman ME, Qureshi AR, Axelsson J, Martola L,Heimb?rger O, Barany P, Stenvinkel P, Lindholm B: Bone mineraldensity in end-stage renal disease patients: Association with wasting, cardiovascular disease and mortality. Blood Purif 2008; 26 (3): 284-290

8. Fontaine MA, Albert A, Dubois B, Saint-Remy A, Rorive G: Fracture and bone mineral density in hemodialysis patients. ClinNephrol 2000; 54 (3): 218-226

9. Spasovski GB: Bone health and vascular calcification relationships in chronic kidney disease. Int Urol Nephrol 2007; 39 (4): 1209-1216

10.London GM, Marty C, Marchais SJ, Guerin AP, Metivier F, deVernejoul MC: Arterial calcifications and bone histomorphometry in end-stage renal disease. J Am Soc Nephrol 2004; 15 (7): 1943-195

11.Zoccali C, Mallamaci F, Tripepi G.Traditional and emerging riskfactors in endstage renal disease. Kidney Int2003;63(suppl 85):S105-S110.

12. Stenvinkel P, Alvestrand A. Inflammation in end-stage renaldisease: sources, consequences, and therapy. SeminDialysis 2002;15:329-337.

13. Busch M, Franke S, M.ler A, Wolf M, Gerth J, Ott U, NiwaT, Stein G. Potential risk factors in chronic kidney disease:AGEs, total homocysteine and metabolites, and the C-reactive protein. Kidney Int 2004;66;3.

14. Prichard S. Risk factors for coronary artery disease in patients with renal failure. Am J Med Sci 2003; 325:209-13.

15.Jaradat MI, Molitoris BA. Cardiovascular disease in patients with chronic kidney disease. Semin Nephrol 2002;22:459-73.

16. Ridker PM, Cushman M, Stampfer MJ. Inflammation, aspirin and the risk of cardiovascular disease in apparently healthy men. N Engl J Med. 1997;336: 973-79. 
17. Ridker PM, Hennekens CH, Buring JE, Rifai N. C-reactive protein and other markers of inflammation in the prediction of cardiovascular disease in women . N Engl J Med. 2000; 342: 836-43

18. KDOQI US Commentary on the 2009 KDIGO Clinical Practice Guideline for the Diagnosis, Evaluation, and Treatment of CKD-Mineral and Bone Disorder (CKDMBD) Am J Kidney Dis 2003;42(suppl 3):S5-S201

19. A H?gh Calc?um- phosphate Product Is Associated With High C-Reaktive Protein Concentrations in Hemodialiysis Patient.Nephron Cl?n Pract 2005;c161-c167

20.Association Between C-Reactive Protein and Biomarkers of Bone and Mineral Metabolism in Chronic Hemodialysis Patients:A Cross-Sectional Study 2009 by the national Kidney Foundation, Inc.All rights reserved

21. Linkage of Elevated with Inflammation in maintenance hemodialysis patients Minerva Urol nefrol 2006;58:339-45

22. Mineral metabolism and inflammation in chronic kidney disease patients: a crosssectional study. Clin J Am Soc Nephrol. 2009 Oct;4(10):1646-54. doi: 10.2215/CJN.02420409. Epub 2009 Sep 24

23. Wanner C, Krane V, M?rz W, Olschewski M, Mann JF, Ruf G, Ritz E; German Diabetes and Dialysis Study Investigators: Atorvastatin in patients with type 2 diabetes mellitus undergoing hemodialysis. N Engl J Med 2005; 353: 238-248

24. Baigent C, Landray MJ, Reith C, Emberson J, Wheeler DC, Tomson C, Wanner C, Krane V, Cass A, Craig J, Neal B, Jiang L, Hooi LS, Levin A, Agodoa L, Gaziano M, Kasiske B, Walker R, Massy ZA, Feldt-Rasmussen B, Krairittichai U, Ophascharoensuk V, Fellstr?m B, Holdaas H, Tesar V, Wiecek A, Grobbee D, de Zeeuw D, Gr?nhagen-Riska C, Dasgupta T, Lewis D, Herrington W, Mafham M, Majoni W, Wallendszus K, Grimm R, Pedersen T, Tobert J, Armitage J, Baxter A, Bray C, Chen Y, Chen Z, Hill M, Knott C, Parish S, Simpson D, Sleight P, Young A, Collins R; SHARP Investigators: The effects of lowering LDL cholesterol with simvastatin plus ezetimibe in patients with chronic kidney disease (Study of Heart and Renal Protection): A randomised placebocontrolled trial. Lancet 2011; 377: 2181-2192

25. Fellstr?m BC, Jardine AG, Schmieder RE, Holdaas H, Bannister K, Beutler J, Chae DW, Chevaile A, Cobbe SM, Gr?nhagen-Riska C, De Lima JJ, Lins R, Mayer G, McMahon AW, Parving HH, Remuzzi G, Samuelsson O, Sonkodi S, Sci D, Suleymanlar G, Tsakiris D, Tesar V, Todorov V, Wiecek A, W?thrich RP, Gottlow M, Johnsson E, Zannad F; AURORA Study Group: Rosuvastatin and cardiovascular events in patients undergoing hemodialysis. N Engl J Med 2009; 360: 1395-1407

26. Abedin M, Tintut Y, Demer LL: Vascular calcification: Mechanisms and clinical ramifications. Arterioscler Thromb Vasc Biol 2004; 24: 1161-1170

27. Gusbeth-Tatomir P, Covic A: Causes and consequences of increased arterial stiffness in chronic kidney disease patients. Kidney Blood Press Res 2007; 30: 97-107

28. Herzog CA, Mangrum JM, Passman R: Sudden cardiac death and dialysis patients. Semin Dial 2008; 21: 300-307 67. Trivedi H, Xiang Q, Klein JP: Risk factors for nonfatal myocardial infarction and cardiac death in incident dialysis patients. Nephrol Dial Transplant 2009; 24: 258-266 
29. Trivedi H, Xiang Q, Klein JP: Risk factors for non-fatal myocardial infarction and cardiac death in incident dialysis patients. Nephrol Dial Transplant 2009; 24: 258-266

30. Danesh J, Whincup P, Walker M, Lennon L, Thomson A, Appleby P, et al. Low grade inflammation and coronary heart disease: prospective study and updated metaanalyses. BMJ 2000;321:199-204.

31. Roivainen M, Viik-Kajander M, Palosuo T, Toivanen P, Leinonen M, Saikku $\mathrm{P}$, et al. Infections, inflammation, and the risk of coronary heart disease. Circulation. 2000;101:252-7.

32. Ridker PM, Cushman M, Stampfer MJ, Tracy RP, Hennekens CH. Inflammation, aspirin, and the risk of cardiovascular disease in apparently healthy men. $\mathrm{N}$ Engl J Med 1997;336:973-9.

33.Tracy RP, Lemaitre RN, Psaty BM, Ives DG, Evans RW, Cushman M, et al. Relationship of C-reactive protein to risk of cardiovascular disease in the elderly.Results from the Cardiovascular Health Study and the Rural Health Promotion Project. Arterioscler Thromb Vasc Biol 1997;17:1121-7.

34. Ridker PM, Cushman M, Stampfer MJ, Tracy RP, Hennekens CH. Plasma concentration of $\mathrm{C}$-reactive protein and risk of developing peripheral vascular disease. Circulation 1998;97:425-8.

35. Rost NS, Wolf PA, Kase CS, Kelly-Hayes M, Silbershatz H, Massaro JM, et al. Plasma concentration of C-reactive protein and risk of ischemic stroke and transient ischemic attack: the Framingham study. Stroke 2001;32:2575-9.

36. Lowe GD, Yarnell JW, Rumley A, Bainton D, Sweetnam PM. C-reactive protein, fibrin D-dimer, and incident ischemic heart disease in the Speedwell study: are inflammation and fibrin turnover linked in pathogenesis? Arterioscler Thromb Vasc Biol 2001;21:603-10.

37. Ridker PM, Rifai N, Rose L, Buring JE, Cook NR. Comparison of C-reactive protein and low-density lipoprotein cholesterol levels in the prediction of first cardiovascular events. N Engl J Med 2002;347:1557-65.

38. Albert CM, Ma J, Rifai N, Stampfer MJ, Ridker PM. Prospective study of Creactive protein, homocysteine, and plasmalipid levels as predictors of sudden cardiac death. Circulation 2002;105:2595-9.

39. Pradhan AD, Manson JE, Rossouw JE, Siscovick DS, Mouton CP, Rifai N, et al. Inflammatory biomarkers, hormone replacement therapy, and incident coronary heart disease: prospective analysis from the Women's Health Initiative observational study. JAMA 2002;288:980-7.

40. Danesh J, Wheeler JG, Hirschfield GM, Eda S, Eiriksdottir G, Rumley A, et al. $\mathrm{C}$-reactive protein and other circulating markers of inflammation in the prediction of coronary heart disease. N Engl J Med 2004; 350:1387-97.

41. Ballantyne CM, Hoogeveen RC, Bang H, Coresh J, Folsom AR, Heiss G, et al. Lipoprotein-associated phospholipase $\mathrm{A} 2$, high-sensitivity $\mathrm{C}$-reactive protein, and risk for incident coronary heart disease in middle-aged men and women in the Atherosclerosis Risk in Communities (ARIC) study. Circulation 2004;109:837-42. 
Table 1. General features of the patients

\begin{tabular}{|l|c|}
\hline Feature & $(\mathrm{N}=91)$ AVG. \pm std, $\%$, median \\
\hline Age & $63.96 \pm 13.34$ \\
\hline Gender & $43(47.3 \%)$ \\
Male & $48(52.7 \%)$ \\
Female & \\
\hline Primary disease & $4(4.4 \%)$ \\
Amyloidosis & $39(42.9 \%)$ \\
Diabetes & $22(24.2 \%)$ \\
Hypertension & $15(16.5 \%)$ \\
Idiopathic & $1(1.1 \%)$ \\
Neurogenic bladder & $2(2.2 \%)$ \\
Pyelonephritis & $6(6.6 \%)$ \\
Polycystic kidney & $1(1.1 \%)$ \\
Toxic nephropathy & $1(1.1 \%)$ \\
Vesicoureteral reflux & $1.52 \pm 0.17$ \\
\hline Kt/v & $8.88 \pm 0.68$ \\
\hline Calcium & $4.95 \pm 1.31$ \\
\hline Phosphorus & $83(91.2 \%)$ \\
\hline It is known that & \\
\hline HsCRP & $29.08 \pm 12.46$ \\
\hline PTH & 2.2 \\
\hline WBC & 360 \\
\hline PLT & $206.21 \pm 79.66$ \\
\hline Albumin & 3.8 \\
\hline Ischemic heart disease & \\
Present & $(68.1 \%)$ \\
Absent & \\
\hline Peripheral vascular disease & \\
Present & \\
Absent & \\
\hline
\end{tabular}


Table 2. Comparison of biochemical parameters of patients with and without Ischemic Heart Disease

\begin{tabular}{|l|c|c|c|}
\hline Parameter & $\begin{array}{c}\text { IHD present } \\
\text { Avg } \pm \text { std or median }\end{array}$ & $\begin{array}{c}\text { IHD absent } \\
\text { Avg } \pm \text { std or median }\end{array}$ & P value \\
\hline Kt/v & $1.49 \pm 0.17$ & $1.59 \pm 0.17$ & $\mathbf{0 . 0 0 5}$ \\
\hline Calcium & $9.12 \pm 0.62$ & $8.76 \pm 0.68$ & $\mathbf{0 . 0 1 5}$ \\
\hline Phosphorus & $5.57 \pm 1.55$ & $4.62 \pm 1.04$ & $\mathbf{0 . 0 0 4}$ \\
\hline It is known that & $50.86 \pm 14.52$ & $40.57 \pm 9.64$ & $\mathbf{0 . 0 0 1}$ \\
\hline HsCRP* & 3 & 2 & $\mathbf{0 . 0 0 2}$ \\
\hline PTH* & 373 & 344 & 0321 \\
\hline WBC & $6.83 \pm 1.58$ & $6.72 \pm 1.31$ & 0.754 \\
\hline PLT & $210 \pm 76.07$ & $198.87 \pm 59.25$ & 0.479 \\
\hline Albumin* & 3.8 & 3.8 & 0.399 \\
\hline
\end{tabular}


Table 3. Comparison of biochemical parameters of patients who were separated into two groups according to the CaxP cut-off point

\begin{tabular}{|c|c|c|c|}
\hline Parameter & $\begin{array}{c}\text { Group A }(\operatorname{CaxP} \geq 55) \\
\mathrm{n}=59 \\
\text { Avg } \pm \text { std, median, } \mathrm{n} \text { and } \%\end{array}$ & $\begin{array}{c}\text { Group B }(\mathrm{CaxP}<55) \\
\mathrm{n}=32 \\
\text { Avg } \pm \text { std, median, } \mathrm{n} \text { and } \%\end{array}$ & $P$ value \\
\hline $\mathrm{Kt} / \mathrm{v}$ & $1.58 \pm 0.17$ & $1.51 \pm 0.17$ & 0.179 \\
\hline Calcium & $9.24 \pm 0.39$ & $8.81 \pm 0.70$ & 0.002 \\
\hline Phosphorus & $6.88 \pm 0.87$ & $4.56 \pm 1.01$ & 0.001 \\
\hline $\begin{array}{l}\text { It is known } \\
\text { that }\end{array}$ & $63.59 \pm 7.86$ & $40.22 \pm 9.14$ & 0.001 \\
\hline HsCRP & $6.96 \pm 2.76$ & $2.00 \pm 0.96$ & 0.001 \\
\hline $\mathrm{PTH}^{*}$ & 521 & 329 & 0.049 \\
\hline WBC & $6.80 \pm 1.53$ & $6.72 \pm 1.28$ & 0.834 \\
\hline PLT & $208.99 \pm 73.97$ & $192.13 \pm 50.28$ & 0.402 \\
\hline Albumin* & 3.8 & 3.8 & 0.825 \\
\hline $\operatorname{IHD} n(\%) \dagger$ & $23 / 59(38)$ & $10 / 32(32.2)$ & 0.001 \\
\hline $\operatorname{PVD} n(\%) \dagger$ & $7 / 59(9.1)$ & $1 / 32(6.7)$ & 0.001 \\
\hline
\end{tabular}

*Mann Whitney U test, † Fisher Exact test, student $\mathbf{t}$ test

Figure 1.CaxP and HsCRP relationship in hemodialysis patients

Figure 2. CaxP and HsCRP relation in hemodialysis patients with and without ischemic heart disease

$$
\begin{array}{cc}
\text { Group A } & \text { Group B } \\
\text { CaxP } \geq 55, \mathrm{n}=59 & \mathrm{CaxP}<55, \mathrm{n}=32
\end{array}
$$

Figure 3.Relationship between CaxP and HsCRP according to the cut-off value of $55 \mathrm{mg} / \mathrm{dl}$ in hemodialysis patients 